\title{
Followership in the School Context
}

\author{
Vaughan Cruickshank \\ Faculty of Education, University of Tasmania, Launceston, Tasmania, Australia \\ Email:V.J.Cruickshank@utas.edu.au
}

How to cite this paper: Cruickshank, V. (2017). Followership in the School Context. Open Journal of Leadership, 6, 95-103. https://doi.org/10.4236/oj1.2017.63006

Received: June 29, 2017

Accepted: August 6, 2017

Published: August 9, 2017

Copyright $\odot 2017$ by author and Scientific Research Publishing Inc. This work is licensed under the Creative Commons Attribution International License (CC BY 4.0).

http://creativecommons.org/licenses/by/4.0/

\begin{abstract}
This paper focused on investigating the leader-follower relationship to determine the influence that effective followers have in regards to the success or failure of their leader within the school context. Just as a teacher needs to be informed as to the needs and abilities of their students, a leader needs to possess similar knowledge in regards to their followers. Followers have traditionally been neglected in leadership research and seen as simply passive recipients of leadership. Leadership and followership represent two sides of one dynamic relationship; without followers, there can be no leaders. This means that followers' behaviors are a vital component of the leadership process, and that leadership cannot be fully understood without an understanding of followership. This paper will examine these follower behaviors and the influence that they can have on school leadership.
\end{abstract}

\section{Keywords}

Followership, Leadership, Leader-Follower Relationship, Influence of Followers, Exemplary Followers

\section{Introduction}

What makes people prepared to follow one leader, but unwilling to follow another? Just as a teacher needs to be informed as to the needs and abilities of their students, a leader needs to possess similar knowledge in regards to their followers (Chaleff, 1996). There appears to be no limit to the quest for understanding in regard to the concept of leadership, yet until recently, followers have been as simply passive recipients of leadership, and largely neglected by researchers (Oc \& Bashshur, 2013). Leadership and followership represent two sides of one dynamic relationship; without followers, there can be no leaders. Followership can be defined as "the characteristics, behaviors, and processes of individuals acting in relation to leaders" (Uhl-Bien, Riggio, Lowe, \& Carsten, 2014: p. 96). This means that followers' behaviors are a vital component of the 
leadership process, and that leadership cannot be fully understood without an understanding of followership. The purpose of this paper is to investigate the leader-follower relationship to determine the influence that effective followers have in regards to the success or failure of their leader within the school context.

\section{Context}

The leader-follower dynamic will be analyzed in relation to one of the author's previous teaching experiences. The context of these experiences was an Australian elementary school which catered for approximately 300 students from kinder to year six. The school had approximately 40 teaching and non-teaching staff. The author worked under the leadership of two different principals at this school; the second of whom (Leader Two) rose to the position after they led a follower-initiated motion of no confidence in the first (Leader One). Leader One was not willing to adapt their behavior or leadership style to better suit their followers. They created a stressful environment by being very reactive, and offended many teachers and parents with their abrasive demeanor and unwillingness to listen to the opinions of others. Following a series of major incidents and complaints from both teaching staff and parents, the school board dismissed them from their leadership position. This situation demonstrates that the power of united followers have the potential to move, and in this case, remove the leader. Kellerman (2007a) notes that bad leaders often retain a small but strong group of supporters even when their inadequacies are exposed. This situation was indeed the case here, and might be representative of the different ways and reasons people follow others. This support group included administration staff and teachers, many of whom were not held in high regard by the majority of staff. Most of this group in support of Leader One resigned and left the school shortly after, as their protection from this leader had been removed. The examination of this context will occur through the lens of Kelley's $(1988$; 1992) followership styles and the followership behaviors identified by Uhl-Bien et al. (2014).

\section{Followership Styles and Behaviors (Kelley, 1988; Uhl-Bien et al., 2014)}

Kelley $(1988 ; 1992)$ is often cited as the key theorist to bring the issue of followership to the attention of researchers, and his work remains the standard in the field (Martin, 2008). He considered followers as important members with as much say and responsibility as leaders. His model of followership categorized followers into five distinct styles according to the dimensions of independent thinking and active participation. Followers who are independent, critical thinkers think about the impact of their actions, are prepared to be creative and innovative, and can offer criticism. Dependent, uncritical thinkers only do what they are told and submit to their leader's thinking. The second dimension, acting, is used to determine what perception of ownership the follower shows. An active follower takes initiative in decision making, while a passive follower's in- 
volvement is limited to being told what to do.

Kelley's (1988; 1992) typology divides followers into quadrants using dependent-independent and passive-active as the axis. The five followership styles are alienated followers, exemplary followers, conformist followers, passive followers, and a central group in the middle of the two dimensions who are labelled pragmatist followers. Alienated followers are capable independent thinkers but are less likely to actively involve themselves in the school. They are cynical and skeptical. They are able to critically evaluate but this analysis does not turn into actions. The opposite of alienated is the conformist followers. They are the "yes people" of the school; actively involved but not capable of independent thinking. They trust in leadership to make decisions for them and will actively follow orders. They fit the traditional definition of a good follower (Kellerman, 2007b). Pragmatist followers are capable of thinking and acting on their own but have only a limited ability to follow through. They perform only the basic requirements of their job and actively seek not to "rock the boat" by under or overachieving. Passive followers do not display independence or actively participate. They rely on leaders to constantly direct them, motivate them and do the thinking for them. Exemplary followers are independent, innovative, and willing to question leadership. They know how to work well with others, present themselves consistently to all who come into contact with them, and can easily adjust to a changing workplace. Kelley (1992) advocated for turning all followers into exemplary followers in order to achieve organizational success. This model may seem to inflict some false rigidity on follower behavior, but followers can move from one style to another just as leaders' styles can vary depending on the situation. Just as leaders will have a dominant style, so too will followers.

Role-based views of followership consider the kinds of behaviors people use to display leadership and followership within the context of hierarchical roles. These views are in line with traditional approaches to studying leadership, however they "reverse the lens" by considering followers, not leaders to be the causal agents (Shamir, 2007). Therefore, follower traits and behavioral styles as examined as antecedents to leader attitudes and behavioral outcomes. Uhl-Bien et al. (2014) identified four key role-based follower behaviors; obedience and subordination, resistance, proactive behaviors, and influencing tactics. The behaviors most relevant to the context of this paper are resistance and proactive behaviors.

Constructive resistance is characterized by followers attempting to discuss, negotiate and clarify issues with leaders, whereas dysfunctional resistance involves passive-aggressive responses such as followers acting too busy to complete requests, or pretending they did not hear them. Tepper et al. (2006) noted that leaders were likely to view the same constructive negotiation attempts very differently based on their relationship with the follower in question. Tepper et al. noted that leaders were receptive to negotiation with followers that they had a close work and social relationship with, but tended to view the same strategy negatively from followers who did not fit into this category. This leadership be- 
havior can lead some followers to change their resistance style from constructive to dysfunctional.

Proactive behaviors are the deliberate actions taken by followers as they plan and act on their environment in order to influence or change it (Uhl-Bein et al. 2014). These behaviors can include seeking feedback, taking charge behavior, and influencing work structures. Proactive followership behavior is often viewed as instrumental to group success, however, it is not always viewed positively by leaders. These follower initiated behaviors can affect the power dynamics of the leader-follower relationship, and be interpreted by leaders as insubordination and a threat to their authority (Benson et al., 2016). The author observed followers exhibiting both resistance and proactive behaviors under the leadership of the two different school principals referred to in this paper.

\section{The Leader and the Follower within the School Context}

Many schools assume that leadership has to be taught but they often assume that everyone already knows how to follow (Kelley, 1988). Therefore, followership is rarely discussed when schools seek to better themselves. Instead, the focus turns to developing leadership skills (Bennis, 2010). One reason that there is so little focus on followership arises from a misconception that leadership is more important than followership (Bjugstad, Thach, Thompson, \& Morris, 2006). The assumption that good followership is purely doing what one is told, and that successful task completion is solely the result of good leadership, does not adequately substantiate the follower role. Typical schools find that most of their work is performed by followers, not leaders (Kelley, 1992). This suggests that when followers feel like valued members and management is prepared to invest in their continued improvement, school achievements can be enhanced. The effectiveness of a leader is to a great extent dependent on the willingness and consent of their followers (Bjugstad et al., 2006), as leaders need to secure the hearts and minds of followers in order to function effectively. This relationship suggests that leadership attitude, behavior and performance could be reflective of successful followership rather than successful leadership. My own experiences as a teacher and a follower within the school context suggest that this is indeed the case.

An effective leader-follower dynamic is characterized by a strong mutually supportive relationship between peers, although one party officially has the final authority. Leader One did not develop strong relationships with many of their staff for a number of reasons. These reasons centred on their inability to look ahead, and their interactions with their staff. Their leadership style caused them to be very reactive when issues arose and they often made quick decisions without adequately consulting relevant stakeholders. Leader One usually discussed issues within their small group of loyal supporters who they relied on for friendship and support, but was less inclined to consult other staff who their decisions affected. This strategy placed them in a "bubble" of sorts as these con- 
formist followers supported their actions and decisions, and did not make them aware of the stress they caused to other staff. Leader One may therefore not have been aware of the feelings and opinions of the majority of their followers.

Kelley $(1988$; 1992) stated that providing unconditional support to leader actions regardless the content of the behavior was a characteristic of ineffective conformist followers. Despite being in a leader-follower relationship this group were socially close and interacted with each other frequently. Their behavior supported Oc and Bashshur's (2013) proposal that followers who are more socially immediate, and have more frequent interactions with leaders exert greater influence over them. Oc and Bashshur noted that supportive follower behavior can earn the follower credit for being loyal but generally does not change leader judgments. This suggests that this follower behavior, while not influencing the current decision, could result in this follower being able to influence future leader decisions they feel more strongly about, and encourage the leader to cover for any of their work related shortcomings.

The author observed that many of his fellow followers initially displayed constructive resistance behaviors and were willing to participate in discussions and negotiations with Leader One about their reactive decisions, but became reluctant to speak up after their opinions were continually ignored. Most leaders can only use their power well over time if they are surrounded by followers who have the courage and skill to successfully give their leaders honest feedback and tell unattractive truths when required. This is a major challenge for followers, especially when their working conditions do not encourage or permit them to do so (Kelley, 1988). The rejection and ignoring of attempts by followers to negotiate and seek feedback led to a breakdown in communication between leader and followers, dysfunctional resistance behaviors, and efforts by followers to minimize interaction with leadership whenever possible. Eventually this situation became unworkable and forced these followers to take action. Their taking charge behaviors included compiling a list of leader behaviors that they viewed as unfair or inappropriate and presenting these to the school board. The high level of agreement within the unhappy follower group made their united voice very influential.

Unfortunately for Leader One the followers in their support group were not highly respected by other staff in the school, primarily because of their unprofessional behavior. In contrast, Leader Two did consult higher status followers. These high status followers were considered as leaders amongst their peers despite not having any official lead teacher title. Staff came to them with concerns and they in turn consulted others before giving their opinions to Leader Two. This change coincided with Leader Two actively developing and maintaining positive relationships with all their staff. They demonstrated the high value they placed on their followers by listening to their opinions and giving them more influence in decisions that affect them. Subsequently, they acted and led in such a way to further promote mutual support amongst all their staff. An example of 
this is their acknowledgement of staff efforts with regular thank you notes. This behavior was in stark contrast to their predecessor.

\section{Follower Characteristics}

Distinguishing the characteristics that separate effective and ineffective followers is an important steps towards organizational success. Kelley (1988) stated that an effective follower exhibits enthusiasm, intelligence, and self-reliance. They have independent and critical thinking skills, are versatile, intent on high performance, and can ease the burden on their leaders by looking ahead to see what needs to be done. Effective followers within the school context can succeed without strong leadership because they are committed to a purpose, principle, or person outside themselves, whether it be commitment to upholding their schools' values, or helping their students to achieve to their full potential. Effective followers are different from ineffective followers in terms of their enthusiasm and self-reliant participation in the pursuit of school goals. According to Bjugstad et al. (2006) ineffective followers are often cynical and critical, and will only do the bare minimum requested of them. These followers typically spend too much time focusing on things beyond their control and become experts at blaming others for their problems.

Large groups of followers will display a range of followership styles, and these styles can change over time depending on their work environment. Under Leader One, the author noted example of numerous followership styles with the majority of staff displaying alienated, pragmatist or conformist behaviors. The change in leadership from Leader One to Leader Two resulted in numerous staff members changing their predominant followership style. The most obvious change was in the previously alienated followers who began to display exemplary follower behaviors. These followers became more actively involved in the school as they were confident that their opinions and concerns would be heard and considered. They became less cynical, more positive, and focused their thinking and evaluation skills on ways to improve teaching and learning. Similar changes were noted in the previously pragmatic followers. These teachers had previously avoided leadership whenever possible and just performed the minimum requirements of their job. They also became much more active and engaged in the school, and display similar exemplary follower behaviors.

\section{Follower Motivations}

A follower's motivation is a function of environmental and internal factors (Bjugstad et al., 2006). Green (2000) discussed three conditions that must be present for followers to be highly motivated. Firstly they must be confident that they can do the job expected of them. Then they must trust their leader to connect outcomes to performance. Lastly, the followers need to find fulfilment with the outcomes they receive. If performance is unsatisfactory, it is likely that one of these three conditions is not being met. Common causes for a follower's lack of 
confidence could be the fact they are under skilled, or that expectations are unrealistic or unclear. Leader One often did not clearly state expectations and would become annoyed with staff when they sought clarity. This increased staff stress as teachers were not confident of exactly what was required of them, and were reluctant to ask for help. These problems could possibly have been alleviated by increased professional development and training along with improved clarification of expectations. Many of these staff had been teaching at the school long before Leader One arrived and had been led with much greater effectiveness previously. It could be argued that their increased disenchantment with their leader and willingness to initiate change was as a result of their positive experiences with previous leaders; and the comparisons they could draw between them.

Followers motivate themselves, rather than drawing their energy and aims from their leader (Hughes, 1998). When a leader communicates trust and respect for followers' abilities to perform and achieve, the internal motivation of the followers drives them to succeed. Leader Two fostered an environment of mutual trust and support which resulted in staff being much more motivated to work hard and contribute to school success and improvement. Chaleff (1996) noted that the more followers support, and stand up for their leader, the stronger their position will be when they stand up to their leader. The more positive atmosphere nurtured by Leader Two encouraged staff to offer and opinions and ask questions about decision. This increased engagement from stakeholders allowed decisions to be enacted more quickly as followers felt ownership over these decisions because they had been involved in the decision process.

Followers determine their commitment to the organization by reflecting on how hard they will work, what type of acknowledgment or reward they might receive, and if that reward will be worth it (Strebel, 1996). When followers are committed to contributing, they respond not only to the direction of their leader, but deliver results because their leaders have moved out of their way (Bjugstad et al., 2006). Leader Two took the time to clearly state expectations and made themselves available to answer questions if required. There was also a much stronger perception that they would support teachers when required. Motivation may also depend on the relationship between the follower and leader. If both have similar values and beliefs, the motivational need for empowerment may not be as high because the follower is driven by the bond with the leader (Mumford, Dansereau, \& Yammarino, 2000). Having worked at the school for nearly twenty years under several different leaders, Leader Two has a good understanding of their followers and the culture of the school. A lot of the changes have been subtle; but the atmosphere was noticeably more positive because of their proactiveness and availability; and their approachable and cheerful personality.

\section{Conclusion}

This paper has investigated the leader-follower relationship and shown the pow- 
er and influence that effective followers can have in regards to the success or failure of their leader within the school context. Both leaders and followers share the responsibility for minimizing bad leadership and maximizing good leadership (Kellerman, 2007a). Providing personal development in followership to leaders in schools might provide insight for leaders into how they can better manage their followers and develop mutually supportive relationships. It should also provide insight to leaders on followership styles, behaviors and motivations. Schools should ensure that leaders feel secure enough in their own position so that they are happy to develop a climate which encourages and celebrates follower development (Martin, 2008). By nurturing and institutionalizing followership, school leaders can ensure their legacy lasts long after their time in charge. In light of the evidence presented in this paper, it might be suggested that bad leadership could be avoided by ensuring leaders are fully aware of the various roles and responsibilities held by the follower. Leaders need to be sensitive to the needs of the follower and aware of the power that the follower holds in relation to successful leadership. The sensible leader will ensure this power is always maintained at the appropriate balance in order to maintain successful, satisfying and mutually beneficial relationships, fostering exemplary followership. In future examinations of followership, I support Shamir's (2007) call for research that reverses the lens and takes a balanced approach which views both leaders and followers as co-producers of leadership and its outcomes.

\section{References}

Bennis, W. (2010). Art of Followership. Leadership Excellence, 27, 3.

Benson, A. J., Hardy, J., \& Eys, M. (2016). Contextualizing Leaders' Interpretations of Proactive Followership. Journal of Organizational Behavior, 37, 949-966. https://doi.org/10.1002/job.2077

Bjugstad, K., Thach, E. C., Thompson, K. J., \& Morris, A. (2006). A Fresh Look at Followership: A Model for Matching Followership and Leadership Styles. Journal of Behavioral and Applied Management, 7, 304-319.

Chaleff, I. (1996). Effective Followership. Executive Excellence, 13, 16.

Green, T. (2000). Motivation Management. Palo Alto, CA: Davies-Black Publishing.

Hughes, M. L. (1998). Keeping Your Job While Your Bosses Are Losing Theirs. Binghamton, NY: William Neil Publishing.

Kellerman, B. (2007a). Bad Leaders. Leadership Excellence, 24, 17.

Kellerman, B. (2007b). What Every Leader Needs to Know about Followers. Harvard Business Review, 85, 84-91.

Kelley, R. (1988). In Praise of Followers. Harvard Business Review, 66, 142-148.

Kelley, R. (1992). The Power of Followership. New York, NY: Doubleday.

Martin, R. (2008). Followership: The Natural Complement to Leadership. FBI Law Enforcement Bulletin, 77, 8.

Mumford, M. D., Dansereau, F., \& Yammarino, F. J. (2000). Followers, Motivations and Levels of Analysis: The Case of Individualized Leadership. Leadership Quarterly, 11, 313-340. 
Oc, B., \& Bashshur, M. R. (2013). Followership, Leadership and Social Influence. The Leadership Quarterly, 24, 919-934.

Shamir, B. (2007). From Passive Recipients to Active Co-Producers: The Roles of Followers in the Leadership Process. Follower-Centered Perspectives on Leadership: A Tribute to JR Meindl. Stamford, CT: Information Age Publishing.

Strebel, P. (1996). Why Do Employees Resist Change? Harvard Business Review, 74, 86-92.

Tepper, B. J., Uhl-Bien, M., Kohut, G. F., Rogelberg, S. G., Lockhart, D. E., \& Ensley, M. D. (2006). Subordinates' Resistance and Managers' Evaluations of Subordinates' Performance. Journal of Management, 32, 185-209. https://doi.org/10.1177/0149206305277801

Uhl-Bien, M., Riggio, R. E., Lowe, K. B., \& Carsten, M. K. (2014). Followership Theory: A Review and Research Agenda. The Leadership Quarterly, 25, 83-104.

Submit or recommend next manuscript to SCIRP and we will provide best service for you:

Accepting pre-submission inquiries through Email, Facebook, LinkedIn, Twitter, etc. A wide selection of journals (inclusive of 9 subjects, more than 200 journals)

Providing 24-hour high-quality service

User-friendly online submission system

Fair and swift peer-review system

Efficient typesetting and proofreading procedure

Display of the result of downloads and visits, as well as the number of cited articles Maximum dissemination of your research work

Submit your manuscript at: http://papersubmission.scirp.org/ Or contact ojl@scirp.org 